\title{
Effect of Sodium Sulfate Addition on the Production of Ferronickel from Lateritic Ore
}

\author{
T.T. PARLAK* AND K. YILDIZ \\ Sakarya University, Faculty of Engineering, Department of Metallurgical and Materials Engineering, \\ Esentepe Campus, Sakarya 54187, Turkey
}

\begin{abstract}
Lateritic nickel ore from Manisa - Çalda $\breve{g}$ region was roasted to form ferronickel at $1200{ }^{\circ} \mathrm{C}$ for $1 \mathrm{~h}$ with additions of metallurgical coke and sodium sulfate varying by weight $5-15 \%$ and $0-20 \%$, respectively. Formed metallic part of roasted sample was separated from non-metallic part by magnet and examined by means of X-ray diffraction analysis and scanning electron microscopy. In spite of kamacite $\alpha$ - $(\mathrm{Fe}, \mathrm{Ni})$ formation, iron-rich silicate structure that causes iron losses was observed for samples roasted with only coke. Kamacite formation increased with increment of the coke percentage but iron-rich silicate structure remained almost same. With addition of sodium sulfate, elimination of iron-rich silicate phase was achieved and easily magnetizable metallic particles were obtained.
\end{abstract}

DOI: 10.12693/APhysPolA.129.485

PACS/topics: 88.10.jn

\section{Introduction}

Area of usage for nickel can be represented as ferrous and non-ferrous alloy industry, petrochemical works, nickel based catalysts and battery production [1]. World nickel reserves comprise of sulfide and lateritic types of ores. While lateritic types of reserves comprise of $73 \%$ world's nickel resources, sulphide ores are preferred for nickel production [2]. Because of deperdition of sulfide reserves and in respect of traditional pyrometallurgical methods, production of nickel costs increase, laterite becomes available source [3]. Laterite ores are homogeneous mixture that comprises of hydrated iron oxides and hydrous magnesium silicates [4]. Depending on the minerals type, nickel presents as substitution in atomic structure of iron and magnesium. Three methods can be used for nickel production; pyrometallurgical, hydrometallurgical and Caron process. Pyrometallurgical process which has high energy consumption can be used for ferronickel production or matte smelting. For ferronickel production, first principle for laterite smelting is while nickel oxide and iron oxide can be reduced to nickel and iron easily, like $\mathrm{Al}_{2} \mathrm{O}_{3}$ and $\mathrm{MgO}$, the other oxide cannot be readily reduced. Bonds between oxygen and aluminum or magnesium are stronger than the bonds between oxygen and iron or nickel. Behavior of $\mathrm{SiO}_{2}$ and $\mathrm{Cr}_{2} \mathrm{O}_{3}$ are different and that means that ferronickel generally contains silicon and chromium [4].

\section{Experimental methods}

Laterite was obtained from Çaldağ Nickel Mining Corporation located in Manisa, Turkey. It was reductively

\footnotetext{
*corresponding author; e-mail: ttunc@sakarya.edu.tr
}

roasted with metallurgical coke with addition of sodium sulfate. Before roasting studies, crushed and sieved under $75 \mu \mathrm{m}$, raw material characterization was done by means of X-ray fluorescence (XRF) with Bruker AXS S8 Tiger and X-ray diffraction (XRD) with Rigaku Ultima X-ray diffractometer. For reduction roasting studies initially carbon ratio was determined and sodium sulfate efficiency was tried to determine via on this ratio. Reductive roasting studies were done in muffle furnace at $1200^{\circ} \mathrm{C}$ for $1 \mathrm{~h}$ at atmospheric conditions in graphite pot on the purpose of providing requirement of reduction. Firstly furnace was heated at desired temperature and homogeneously mixed blend placed within the pot. After $1 \mathrm{~h}$ graphite pot was taken and cooled at room temperature. Roasting process caused compaction of the blend so that compacted product was grounded and powders were magnetized with magnet manually. Formed phases in magnetized part of the product was analyzed with XRD and microstructural characterization was done with JEOL 6060 LV SEM.

\section{Results and discussion}

Chemical composition and phases of the laterite are given in Table I and Fig. 1, respectively. Laterite used as raw material is rich in silicon and iron as understood from Table I. Phase analysis of laterite shows that silicon is available in the form of quartz that detected as major phase and iron is available in the forms of goethite and hematite that were detected as minor phases.

TABLE I

Chemical composition of laterite used as raw material.

\begin{tabular}{c|c|c|c|c|c|c|c|c|c|c}
\hline \hline \multicolumn{10}{c}{ Components [wt\%]. } \\
\hline $\mathrm{Fe}_{2} \mathrm{O}_{3}$ & $\mathrm{SiO}_{2}$ & $\mathrm{Al}_{2} \mathrm{O}_{3}$ & $\mathrm{MgO}$ & $\mathrm{NiO}$ & $\mathrm{Cr}_{2} \mathrm{O}_{3}$ & $\mathrm{~K}_{2} \mathrm{O}$ & $\mathrm{CaO}$ & $\mathrm{MnO}$ & $\mathrm{TiO}_{2}$ & $\mathrm{CoO}$ \\
\hline 46.6 & 37.49 & 9.17 & 2.67 & 1.44 & 0.836 & 0.562 & 0.531 & 0.402 & 0.224 & 0.075
\end{tabular}

Reductively roasted laterite with metallurgical coke with different percentage by weight in the absence of 


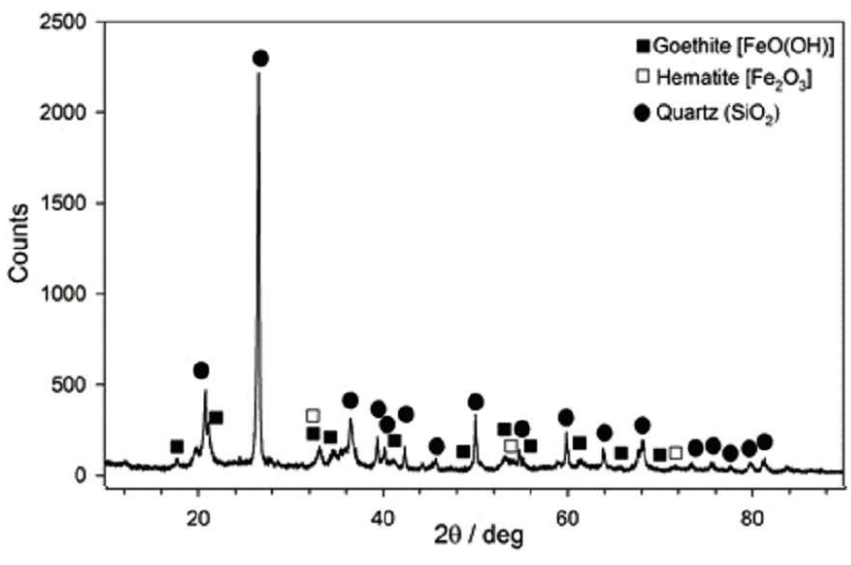

Fig. 1. XRD analysis of the laterite used as raw material.

sodium sulfate are shown in Fig. 2. With 5 wt\% additive, dominantly iron silicate phase formation was detected. Beside iron silicate, cristobalite, quartz, formation of kamacite and taenite were observed. Decrement of the iron silicate and quartz in parallel with increment of the cristobalite and kamacite occurred with raised carbon ratios. As the strong peak of kamacite was determined at prepared with $15 \mathrm{wt} \%$ carbon sample, metallurgical coke addition was kept constant at this ratio and sodium sulfate studies were tried upon this ratio.

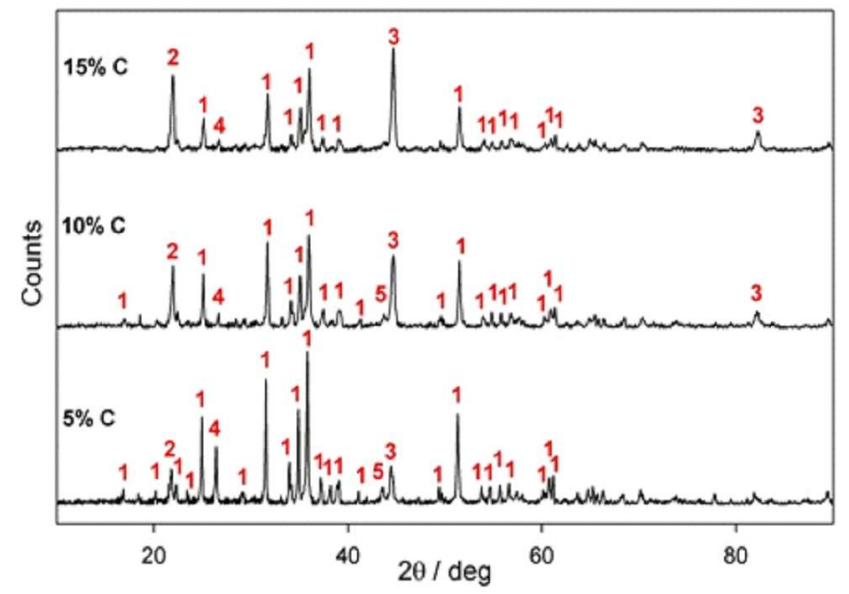

Fig. 2. XRD analysis of roasted samples without $\mathrm{Na}_{2} \mathrm{SO}_{4}$ addition $\left(1-\right.$ iron silicate $\left(\mathrm{Fe}_{2} \mathrm{SiO}_{4}\right), 2-$ cristobalite $\left(\mathrm{SiO}_{2}\right), 3$ - kamacite $[\alpha-(\mathrm{Fe}, \mathrm{Ni})], 4-$ quartz $\left(\mathrm{SiO}_{2}\right), 5$ - taenite $\left.[\gamma-(\mathrm{Fe}, \mathrm{Ni})]\right)$.

Effect of sodium sulfate addition on the phase formation can be seen in Fig. 3. Because the diffraction angles of the formed phases are so closed, graph at the left side gives diffraction angles between $20^{\circ}$ and $46^{\circ}$ for exhibiting minor phases of the product and right side gives diffraction angles entirely. While cristobalite and quartz phases were observed at only carbon used samples, addition of sodium sulfate caused elimination of these phases. Jiang et al. stated that reduction of iron and nickel oxide

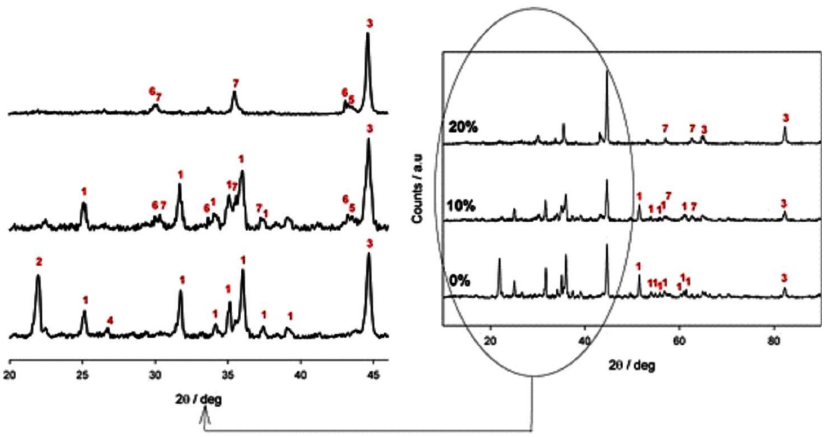

Fig. 3. XRD analysis of roasted samples with 15 wt\% $\mathrm{C}$ and different percentage by weight $\mathrm{Na}_{2} \mathrm{SO}_{4}(1-$ iron silicate $\left(\mathrm{Fe}_{2} \mathrm{SiO}_{4}\right), 2-$ cristobalite $\left(\mathrm{SiO}_{2}\right), 3-$ kamacite $[\alpha-(\mathrm{Fe}, \mathrm{Ni})], 4-$ quartz $\left(\mathrm{SiO}_{2}\right), 5$ - taenite $[\gamma-(\mathrm{Fe}, \mathrm{Ni})], 6$ - iron Sulfide $(\mathrm{FeS}), 7$ - magnetite $\left.\left(\mathrm{Fe}_{3} \mathrm{O}_{4}\right)\right)$.

with carbon occurred approximately at $1200{ }^{\circ} \mathrm{C}$ with by product $\mathrm{CO}$ and $\mathrm{CO}_{2}$ according to reactions $1-6$ given below [5]:

$$
\begin{aligned}
& \mathrm{FeOOH} \rightarrow{ }^{1} /{ }_{2} \mathrm{Fe}_{2} \mathrm{O}_{3}+{ }^{1} /{ }_{2} \mathrm{H}_{2} \mathrm{O}(\mathrm{g}), \\
& 3 \mathrm{Fe}_{2} \mathrm{O}_{3}+\mathrm{CO} \rightarrow 2 \mathrm{Fe}_{3} \mathrm{O}_{4}+\mathrm{CO}_{2}(\mathrm{~g}), \\
& \mathrm{Fe}_{3} \mathrm{O}_{4}+\mathrm{CO} \rightarrow 3 \mathrm{FeO}+\mathrm{CO}_{2}(\mathrm{~g}), \\
& \mathrm{FeO}+\mathrm{CO} \rightarrow \mathrm{Fe}+\mathrm{CO}_{2}(\mathrm{~g}), \\
& \mathrm{NiO}+\mathrm{CO} \rightarrow \mathrm{Ni}+\mathrm{CO}_{2}(\mathrm{~g}), \\
& 2 \mathrm{FeO}+\mathrm{SiO}_{2} \rightarrow \mathrm{Fe}_{2} \mathrm{SiO}_{4} .
\end{aligned}
$$

By taking into consideration these reactions, it can be said that goethite structure existing in laterite undergoes dehydroxylation firstly. If reduction requirement is provided, this reaction will proceed until metallic phase occurrence. But as seen in Fig. 2, reduction was interrupted due to recrystallization of sillicate mineral at insufficient carbon condition. It can be said that, at lower carbon ratios, formed wustite phase cannot be reduced because of the absence of by product $\mathrm{CO}$ arising from carbon and wustite makes compound with silica to form iron silicate phase. According to study on reduction of laterite, it is stated that formation of fayalite $\left(\mathrm{Fe}_{2} \mathrm{SiO}_{4}\right)$ or forsterite $\left(\mathrm{MgSiO}_{4}\right)$ structure interrupts reduction via covering oxide particles [6]. When carbon ratio is increased this time reduction proceed and kamacite formation occurs. From the result of samples containing excess carbon, iron silicate structure still exists but the intensity decreased while kamacite intensity increased. This time quantity of formed wustite phase may be more than the insufficient carbon used sample and formed wustite phase made compounds with both silica and nickel oxide. With addition of $\mathrm{Na}_{2} \mathrm{SO}_{4}$, silicate structure was eliminated. It is thought that silicate structure was kept by sodium. As seen in Fig. 3, by adding sodium sulfate, at the ratio of $10 \mathrm{wt} \%$ despite of iron silicate formation, magnetite and iron sulfide formation occurred. Increasing of the ratio to $20 \mathrm{wt} \%$, silicate structure was completely eliminated. This phenomenon suggest that iron that is trapped by silicate as $\mathrm{Fe}_{2} \mathrm{SiO}_{4}$ was liberated. Jiang et al. also stated sodium sulfate decomposition reaction as below: 
$\mathrm{Na}_{2} \mathrm{SO}_{4}+4 \mathrm{CO} \rightarrow \mathrm{Na}_{2} \mathrm{~S}+4 \mathrm{CO}_{2}(\mathrm{~g})$,

$\mathrm{Na}_{2} \mathrm{SO}_{4}+3 \mathrm{CO} \rightarrow \mathrm{Na}_{2} \mathrm{O}+\mathrm{S}(\mathrm{g})+3 \mathrm{CO}_{2}(\mathrm{~g})$.

Formed $\mathrm{Na}_{2} \mathrm{O}$ gives reaction with silicate mineral and forms nepheline and so that at reductive roasting nickel oxide and iron oxide can be liberated from silicate minerals according to below reaction [5]:

$$
\mathrm{Na}_{2} \mathrm{O}+2 \mathrm{Fe}_{2} \mathrm{SiO}_{4} \rightarrow 4 \mathrm{FeO}+\mathrm{Na}_{2} \mathrm{Si}_{2} \mathrm{O}_{5} \text {. }
$$

Metallic parts of samples are shown in Fig. $4 \mathrm{a}-\mathrm{e}$. As seen from the micrographs, with sodium sulphate addition, metallic parts get bigger than the sample prepared only with carbon. With sodium sulfate addition, it can be said that iron liberation can be achieved besides decrease of iron silicate quantity. Consequently growth of ferronickel particles is important for magnetic separation. If ferronickel particle is so small, it will be impossible to separate metallic part from the oxidized one. Li et al. stated that ferronickel was surrounded by iron sulfide because of first precipitate from melted eutectic of $\mathrm{Fe}-\mathrm{FeS}$. $\mathrm{Li}$ et al. also stated that melted phase is responsible for rapid particle growth and small particles are preferentially precipitate on bigger particles [6].
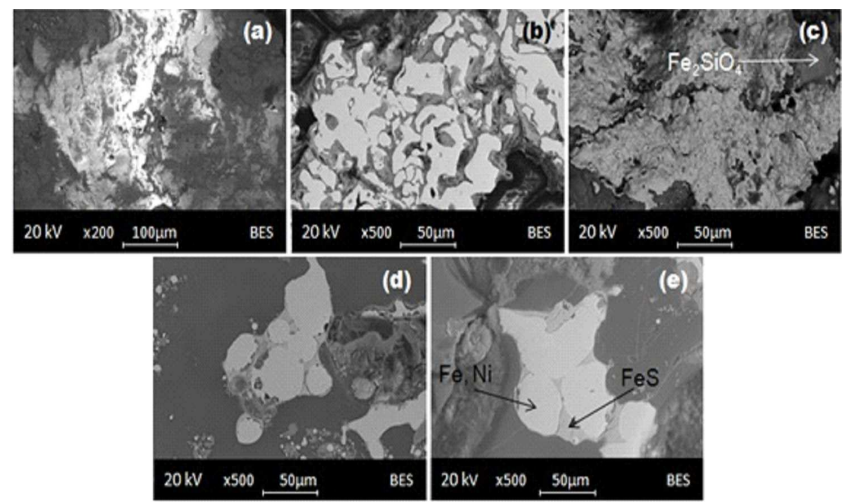

Fig. 4. SEM micrographs of reductively roasted samples: (a) $5 \mathrm{wt} \% \mathrm{C}$, (b) $10 \mathrm{wt} \% \mathrm{C}$, (c) $15 \mathrm{wt} \% \mathrm{C}$, (d) $15 \mathrm{wt} \% \mathrm{C}+10 \mathrm{wt} \% \mathrm{Na}_{2} \mathrm{SO}_{4}$ and (e) $15 \mathrm{wt} \% \mathrm{C}$ $+20 \mathrm{wt} \% \mathrm{Na}_{2} \mathrm{SO}_{4}$.

\section{Conclusion}

Laterite is reductively roasted with metallurgical coke and sodium sulfate addition in this study. It is understood that for reduction of iron and nickel, only carbon addition is not efficient. For all carbon ratios, iron silicate, quartz and cristobalite formation were observed besides kamacite formation and this occurrent caused iron losses. When sodium sulfate was used, $\mathrm{SiO}_{2}$ structure is eliminated but still iron silicate phase presents at the ratio of $10 \mathrm{wt} \% \mathrm{Na}_{2} \mathrm{SO}_{4}$. When the ratio was raised to $20 \mathrm{wt} \% \mathrm{Na}_{2} \mathrm{SO}_{4}$ iron silicate cannot be determined. The other advantage of sodium sulfate is grain growth of metallic particle. The XRD results of $15 \mathrm{wt} \% \mathrm{C}+$ 20 wt $\% \mathrm{Na}_{2} \mathrm{SO}_{4}$ shows only kamacite, magnetite and $\mathrm{FeS}$ and this structure has bigger particles than the others as observed from the SEM analysis.

\section{References}

[1] Ş. Kaya, Y.A. Topkaya, Miner. Eng. 24, 1188 (2011).

[2] İ. Girgin, A. Obut, A. Üçyildiz, Miner. Eng. 24, 603 (2011).

[3] M. Milivojevic, S. Stopic, B. Friedrich, B. Stojanovic, D. Drndarevic, Int. J. Miner. Metall. Mater. 19, 584 (2012).

[4] F.K. Crundwell, M.S. Moats, V. Ramachandran, T.G. Robinson, W.G. Davenport, Extractive Metallurgy of Nickel, Cobalt and Platinum Group Metals, Elsevier, Amsterdam 2011, p. 39.

[5] M. Jiang, T. Sun, Z. Liu, J. Kou, N. Liu, S. Zhang, Int. J. Miner. Process. 123, 32 (2013).

[6] G. Li, T. Shi, M. Rao, T. Jiang, Y. Zhang, Miner. Eng. 32, 19 (2012). 